\title{
Impact of Tourism in the Local Economy of Sauraha ${ }^{1}$
}

- Prabin Dongol

pravindongol@msn.com

This study explores the aspects of Chitwan as a tourist destination. The discussion is based on a field work in Chitwan National Park (CNP), Sauraha.

Chitwan National Park (CNP) was officially established as the first National Park of the country. The total area of CNP is around 932 sq km. The CNP lies in Nepal's Southern border with India, with typical sub-tropical vegetation and oriental fauna. The main entrance gate to the Park and most important tourism trade area within the buffer zone of the CNP is Sauraha. It is one of the ten entry points of the CNP. This important tourism area lies in the Northern border of the CNP along the North bank of Rapti River. According to CNP data from fiscal year 2067/68, altogether 146,622 tourists visited the park among which 111,118 entered through Sauraha. This accounts for $76 \%$ of the total.

Tourists Entering Sauraha in 2067/68

\begin{tabular}{|c|c|c|c|c|c|c|c|c|c|c|c|c|c|}
\hline 童 & $\frac{\pi}{n}$ & 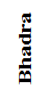 & $\frac{5}{2}$ & 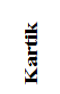 & 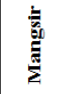 & 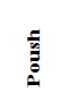 & 预 & $\underset{\frac{5}{E}}{\tilde{E}}$ & שี & 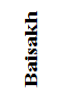 & 吾 & $\frac{5}{2}$ & $\stackrel{\bar{g}}{0}$ \\
\hline Foreign & 4817 & 3442 & 6725 & 9116 & 6467 & 4241 & 5975 & 5534 & 6874 & 6594 & 3311 & 3158 & 66254 \\
\hline SAARC & 505 & 549 & 937 & 1916 & 805 & 1322 & 509 & 690 & 960 & 1878 & 2912 & 1046 & 14029 \\
\hline Nepali & 1380 & 672 & 1405 & 3942 & 3200 & 4975 & 4243 & 3090 & 3251 & 2852 & 1058 & 767 & 30835 \\
\hline Total & 6702 & 4663 & 9067 & 14974 & 10472 & 10538 & 10727 & 9314 & 11085 & 11324 & 7281 & 4971 & 111118 \\
\hline
\end{tabular}

${ }^{1}$ Study funded by NTB. Detailed Report is available with the author. This is a part of the Independent Study undertaken for Master in Development Studies, School of Arts , Kathmandu University, 2012 
There are around 90 small and big hotels and lodges. These accommodation establishments provide food and accommodation services and also organize cultural and other recreational activities for the tourists. Elephant riding, elephant bath, canoeing, boating, jeep safari, jungle walk, camping are some of the popular recreational activities. There are 43 private elephants and 6 government elephants, which provide services to tourists. There is also an elephant breeding center in Sauraha, where tourists can see how elephants are reared.

\section{Accommodation Establishments}

Sauraha has sufficient number of accommodation establishments and restaurants for tourists. Majority of the establishments have offered facilities like attached bathroom and running hot water, cable TV, internet, laundry, guides etc. The occupancy rate of overall establishments is around 89\% during peak season and $40 \%$ during slack season. It was observed that occupancy rate increased with the increase in size of the establishments during both peak and slack seasons. The reason for higher occupancy rate in large establishments may be their stronger network with travel agencies in Kathmandu than that of the smaller establishments.

The tariff rate of rooms has increased with the increase in size of accommodation establishments. Only $49 \%$ of the establishments have reported to have reduced tariff rate during slack season. Small establishments having lower operating cost reduce tariff in slack season to cover up their variable costs. On an average, small establishments offer 18\% discount in rooms, medium establishments offer $10 \%$ and the large ones $5 \%$.

Out of total staffs employed in the accommodation establishments, 53\% are from local area. Most are employed on low level jobs. In average, small establishments have employed 7 staffs, medium establishments 17 and the large 26. The average number of males employed is 10.96 per establishment, 
while that of the females is 1.72 . Only 0.49 staffs in average per establishment are employed temporary during peak season.

Large establishments pay higher salary than smaller establishments. The average salary of males is higher than that of the females. Most of the females are employed in low-level jobs such as cleaning and housekeeping. So, relatively they are paid less. The average salary of temporary staffs, who are hired on a daily basis, is Rs 669 per month. About $52 \%$ of the salary amount is retained within Sauraha.

Only $11 \%$ of the food expense and $10 \%$ of non-food expense is spent in Sauraha. Of the total expense on food, $3 \%$ goes to cereals, $6 \%$ to meat, $11 \%$ beverage, $19 \%$ vegetable and oil and $3 \%$ to other miscellaneous items. Rice, local chicken, local fish, eggs, milk, mineral water and vegetables are the main purchases made in Sauraha.

\section{Restaurants}

The average monthly sales of a restaurant in Sauraha is Rs 24,700 in peak season and Rs. 6933 in slack season. Drinks and snacks are the most popular items among visitors. In average, each small restaurant has employed 5 staffs and each large restaurant has 12 staffs. Of the total number of staffs employed in restaurants, 59\% are from Sauraha. Only one temporary staff was found to have been hired by a restaurant during peak season.

The average employment of males in restaurants is higher than of females. And the ratio of temporary staffs is also lower compared to that of permanent staffs. The average salary of male staffs is higher than that of the females, and the salary of temporary staffs is far lower than that of the permanent staffs. Besides the regular salary, the staffs also get $10 \%$ service charge along with meals, accommodation, uniforms and basic health service. During peak season, in small restaurants, the real income of both male and female staffs is 2.6 times higher than 
their actual salary. In large restaurants, the earning of males is 4 times higher than their regular income, while that of the females is 2.8 times higher. During slack season, the amount remains 1.4 times for males and 1.5 times for females. In large establishments, the real income is 1.8 and 1.9 times higher than actual income for males and females, respectively.

The restaurants purchase only $9 \%$ of the total food items from the local area. Rice, milk, chicken, fish, eggs and mineral water are purchased in the local market. In non-food expenses, 19\% of the total amount is spent locally. Moreover, Sauraha retains $60 \%$ of the total amount expended in salary by the restaurants. But of the total annual expense of the restaurants, only $15 \%$ was is retained in Sauraha.

\section{Outlets}

All the outlets of Sauraha are family businesses. Only family members are involved for operation of the outlets. The average number of male staffs is 1 and that of female staffs 0.96 . The average of the staff is 1.96 . The maximum number of staffs involved in each outlet is 3 in average. During peak seasons, the average sales of grocery and curio shops amount to Rs. 70,556 and Rs. 99,933 per month respectively. During slack season, the sales decline in grocery is about $85 \%$, and in curios shops it is around $84 \%$.

\section{Tourists}

Out of total tourists surveyed, $32 \%$ were Asian and $68 \%$ were westerners. The average length of stay of 16-30 years group was 3 days while average length of stay of the older group was 9 days. It was found that younger tourists spent less money on accommodation and food than older tourists while older tourists spent less money on recreational activities than younger tourists. Expenses according to the length of stay indicated that tourists who stayed less than a week spent more on 
accommodation and food than those who stayed more than a week.

European tourists spent higher amount of money on food, accommodation and recreational activities. The expense of North Americans on accommodation was slightly less than Chinese but they spent more than Chinese on food. Asians, except the Chinese, spent least amount on accommodation, food and recreational activities.

The nature of facility appears to be a major concern of the tourists to Sauraha. About $68 \%$ of them reported that the rate of food is reasonable, $20 \%$ said it was high, and $12 \%$ considered it low. Similarly, the accommodation cost is reasonable for $72 \%$ tourists, and only $12 \%$ take it to be high. Typically, all Europeans consider the accommodation rate low.

Majority of the tourists (53\%) agree that the local map of Sauraha is helpful but not adequate. Others (41\%) consider it helpful and adequate, and only $6 \%$ take it neither helpful nor adequate. All tourists feel positive about the hospitality provided by the local people and security of tourists in the local area. Around $72 \%$ of them feel there is no littering and ecohazards in the local area. Interestingly, $88 \%$ of them are not willing to contribute to the management of garbage, and $92 \%$ are unwilling to pay extra fee for park entry.

\section{Remarks}

The Tourism Year 2011 Marketing and Promotion Campaign, according to $51 \%$ of the respondents, had neither positive nor negative impact on the tourism of Sauraha. About promoting tourism in Sauraha, 53\% of the respondents suggested improvement in the transportation facilities. In the same way, $37 \%$ of them opined that promotion and publicity of Sauraha in national and international level would increase the inflow of tourists. Other suggestions included preservation of the wildlife of the Chitwan National Park, improvement in the 
administration of the National Park, introduction of new and additional recreational activities, security, quality of accommodation establishments, reduction in park permit rate, preservation of traditional culture, facilities for tourist such as ATM, hospitals, public toilet and night life among others.

Tourism industry in Sauraha has generated significant employment opportunities for local people. Although, half of the staffs employed in accommodation establishments and restaurants are locals, most of them are employed in lower level jobs. Hence, proper education and training should be provided to them which will enhance their skills and capability to serve in higher level jobs, and also will increase their income level and improve their standard of living.

Out of the total demand of food items, only around $11 \%$ demand of accommodation establishments and 9\% demand of restaurants is fulfilled by local production. Food products such as milk, eggs, rice, chicken, fish and mineral water are produced in Sauraha, which is consumed by the tourism market but production of these items is very limited which does not fulfill all the demands of the market. The shortages are purchased from markets outside of Sauraha. Thus, if the production of those products were increased, their consumption would also increase in the local market which would increase the income of local people and help them improve their living standard. The production and supply of those local products could be increased significantly if local people initiated the commercial production of those products.

The fact that around half of the respondents reported of neither positive nor negative impact of Tourism Year 2011 indicates that even after investing millions of rupees of government money, government was unable to make the event as successful as it could have been.

Majority of the tourists responded that the maps provided to them were helpful but not adequate. It suggests that map of the local area should be updated frequently which will provide 
adequate information to the tourists. Most of the tourists were unwilling to contribute for the management of garbage. According to them, tourists spend a lot of money for park entry and other recreational activities, so why should they pay extra money. Concerned authorities should allocate certain portion of those fees for the management of garbage disposal and solving eco-hazards.

\section{Works Consulted}

Bhusal, N. P. (2007). Chitwan National Park: A Prime Destination of Eco- Tourism in Central Tarai Region, Nepal. The Third Pole.

Chitwan National Park. (2067/68). Chitwan National Park Annual Report. Kasara, Chitwan: Chitwan National Park Office.

Ministry of Finance. (2009/10). Economic Survey. Kathmandu: Government of Nepal. 